\title{
Unwanted Heritage? Historiographic Discourse about (Second) Yugoslavia
}

\section{IZVLEČEK \\ NEZAŽELENA DEDIŠČINA? HISTORIOGRAFSKI DISKURZ O (DRUGI) JUGOSLAVIJI}

Avtor poskuša $v$ kratkem pregledu predstaviti dojemanje druge jugoslovanske države v slovenskem zgodovinopisju in družbi, saj ostaja jugoslovanska zgodovina v Sloveniji predvsem politična in ne toliko strokovna tema. Vprašanje, kdaj se bo uspela odlepiti od tega, ostaja neodgovorjeno, kljub temu pa ocenjuje, da je potrebno na procese, ki so v preteklosti bili obravnavani izven sirrèega konteksta, včasih pogledati tudi z nekoliko drugačne perspektive.

Ključne besede: Jugoslavija, zgodovina, zgodovinopisje

\section{ABSTRACT}

In a short overview the author attempts to present the attitude towards the second Yugoslav state in the Slovenian historiography and society, as in Slovenia the Yugoslav history remains above all a political rather than expert topic. The question when this flaw will be overcome remains unanswered. Nevertheless, the author estimates that the processes, seen outside of the broader context in the past, should sometimes be viewed from a somewhat different perspective.

Keywords: Yugoslavia, history, historiography

In this article I shall discuss a historical phenomenon called Yugoslavia. It is a country that no longer exists, and allegedly we are all well-aware of this. However, one could ask a direct witness about it: the singer-songwriter Andrej Šifrer, who used to sing at the time of its demise: "Kdo bo za pijačo dal, ko umrla bo država? [Who will buy drinks when the state is dead?]"1

* Research Associate, PhD, Institute of Contemporary History, Kongresni trg 1, 1000 Ljubljana, Slovenia, jurij.hadalin@inz.si

1 Andrej Šifrer, "Država," on: Hiti počasi (Ljubljana: ZKP RTVLJ, 1990). The song was a big hit in the period before the Slovenian independence. More about the circumstances surrounding the creation of this song: "Hiti počasi," Hiti počasi - Wikipedija, prosta enciklopedija, accesed 20 June 2016, https:// sl.wikipedia.org/wiki/Hiti_po\%C4\%8Dasi. 
After all, that is why we are celebrating the $25^{\text {th }}$ anniversary of the independent Slovenian state this year. Nevertheless, Yugoslavia still lives its virtual life, perhaps mostly because it does not actually exist in the political geography; it does not have only a single successor or pretender to its universal heritage; nor does it have a "nation" (neither tripartite, nor from the ranks of the nations and nationalities); although fifteen years ago almost 328,000 Yugoslavs were counted in the United States. ${ }^{2}$ On the basis of the same source (a lecture by Tomasz Kamusella at the Faculty of Arts in Ljubljana ${ }^{3}$ ) we can add that even its unique language has been preserved in the virtual world, as the largest Wikipedia from our territories has been written in what is today the non-existent Serbo-Croatian language. ${ }^{4}$ At this point let me also mention the Yugoslav leader Josip Broz Tito, who is often - in the general as well as professional public - presented as synonymous with the word Yugoslavia. Even he "has lived his virtual life" since as early as 1997, when he started disturbing the public from the servers of the Jožef Stefan Institute. ${ }^{5}$ Thus he lives regardless of reality and not always merely due to the concept of "Yugo-nostalgia", which has in the recent years acquired an increasingly pejorative connotation, especially in the segment of the society which sees the second Yugoslav state especially on the basis of the traumatic events at the time of its establishment. However, perhaps these people can seek solace in the fact that "Yugo-nostalgia" is a typical example of retroutopia, ${ }^{6}$ i.e. nostalgia for something that has in fact never existed, at least not in the idolised form that might be painted today. We could also use the term retronostalgia; however, that is something completely different, as the Radio Student show with the same title underlines with its slogan: "We record, describe and deconstruct selected objects from our consumer past. Unfortunately, however, we cannot deny them."7

Many people associate this nostalgia merely with the political system, and we have to acknowledge, from what is today already a sufficient temporal distance, that it was unique and utopic in its complexity. However, also in terms of geography and culture we have been determined by Yugoslavia to the degree where we cannot

2 In the population census of 2000, 328,547 people declared the Yugoslav, 374,241 Croatian, 140,337 Serbian and 176,691 Slovenian ancestry. See: "United States Census Bureau, American Fact Finder, Ancestry (Total Categories Tallied) for People with One or More Ancestry Categories Reported," American FactFinder - Results, accesed 20 June 2016, http://factfinder.census.gov/faces/tableservices/jsf/pages/productview.xhtml?pid=DEC_00_SF3_PCT018\&prodType=table.

3 Tomasz Kamusella, The Forgotten 1989 Ethnic Cleansing of Bulgaria's Turks. A Yugoslav Connection? (lecture) (Ljubljana: Faculty of Arts and Institute of Contemporary History, 7 June 2016).

4 The Serbo-Croatian version includes 433,561 articles, Serbian 336,321 articles, Croatian 166,093 articles and Slovenian 151,768 articles. See: List of Wikipedias - Meta, accesed 20 June 2016, https:// meta.wikimedia.org/wiki/List_of_Wikipedias\#All_Wikipedias_ordered_by_number_of_articles.

5 Tito's Home Page, www.titoville.com. Website currently unavailable.

6 Jela Krečič, Miglena Nikolčina: Treba je tvegati in si zamisliti utopijo [We Have to Take a Risk and Imagine an Utopia], accesed 1 September 2016, http://m.delo.si/sobotna/miglena-nikolcina-treba-jetvegati-in-si-zamisliti-utopijo.html.

7 Retrostalgija [Retronostalgia] | Radio Študent, http://radiostudent.si/dru\%C5\%BEba/retrostalgija. 
simply overlook it on the occasion of the $25^{\text {th }}$ anniversary of the independent Slovenian state. Dejan Novačić is the curator of this non-existent state: he described the Socialist Federal Republic of Yugoslavia in his well-known work SFRJ za ponavljače (SFRY for Repeaters, in the Slovenian translation SFRJ - moja dežela, or SFRY My Country), ${ }^{8}$ while he developed the Yugoslav mental heritage in the book Emigrantska kuharica9 (Emigrant Cookbook, which explains how the aforementioned 328,000 Yugoslavs have been preserving their culture). In the introduction to the aforementioned "lexicographic study" Miha Avanzo asks himself: "Where do dead countries end up?" 10 The answer is provided by Dubravka Ugrešić, who says: "that Novačičs book is a humorous deconstruction of flowery words, and therefore it has a twofold effect. As we are reading it, we can calmly come to terms with our own past and at the same time forgive it with relief." She also adds: "The value of this book lies in the fact that it is one of the first works to open the space for the revaluation of the past, and not the official past - that is up to historians - but the past of our own lives." 11 And at this point I can think of two things:

1. In the last 25 years, in Slovenia the orphan Yugoslavia has lived in a tumultuous atmosphere, as our former/current actors have been unable to carry out this revaluation in a relaxed-enough spirit. Let me just refer to the recent interview with Stane Granda. "The journalist asked him how it is possible that the youth today - those who were born after the disintegration of Yugoslavia - talk about the fallen state with such a positive attitude. Granda answered that one of the reasons was the false upbringing that perpetuated a myriad of lies and half-truths. One of such lies is that once upon a time everybody had jobs. 'Of course we all had jobs, but people often had nothing to do there,' Granda refuted one of the most frequent blunders. He also reminded everyone to the hilarious processes involved in buying cars and a seriously limited freedom of speech. 'These rights, whose acquisition represents a significant turning point... They do not mean anything to them, as they were born to this, this is their life. When they hear that jobs and apartments existed, it is naturally that they complain - even though I, for one, have never received an apartment, and I nevertheless had to contribute money to the housing fund.' The historian claims that many lies remain, in judiciary as well as in the education system. In schools the lies are reflected in the selected topics. Granda illustrated this with the lessons in history, where the pupils learn when people in Slovenia started wearing jeans, but they do not find out that jeans had to be smuggled from abroad. 'The former system was

8 Dejan Novačić, SFRJ za ponavljače. Turistički vodič [SFRY for Repeaters. A Tourist Guide] (Beograd: Moć knjige, 2003).

9 Dejan Novačić, Emigrantski kuvar. Sve što ste oduvek hteli da znate o jugoslovenskoj kubinji, ali nemate više koga da pitate [Emigrant Cookbook. What You've Always Wanted to Know about the Yugoslav Kitchen, but There's No One Left to Ask] (Novi Sad: Stylos Art, 2009).

10 Miha Avanzo, "Kje končajo mrtve države?," [Where do Dead Countries End Up] in: Dejan Novačić, SFRJ - moja dežela. Turistični vodnik (Ljubljana: Orbis, 2003), 4.

11 Dubrovka Ugrešić, "Leksikon izmišljene dežele," [Lexicon of an Imaginary Country] in: Dejan Novaćić, SFRJ - moja dežela. Turistični vodič (Ljubljana: Orbis, 2003), 5, 6. 
based on lies, and many of these lies remain present in the society,' he stated and added that the various Yugo-nostalgic celebrations in the primary and secondary schools are also the result of the advanced age of the teachers, who are therefore perhaps also slightly demented." 12

2. Yugoslavia no longer exists and it should be the subject of historians. That is what my colleague Zdenko Čepič ${ }^{13}$ has frequently said in the recent years, and it is time that we actually get on with it - soberly and using the standard historiographic methodology. However, we have more or less intensively been doing this also in the last 25 years. And that, actually, is what I wanted to discuss.

In the time of the Second Yugoslavia and its permanent reforms not very many truly Yugoslav/common things were created, despite significant efforts. If we can describe the Yugoslav social reality with precisely three truly common denominators - Tito, Yugoslav People's Army and the blue team - than it is clear that Yugoslav historiography in the classic sense of the word did not exist. Large-scale common project did exist - from the History of the Communist Party of Yugoslavia/ League of Communists of Yugoslavia to the Encyclopaedia of Yugoslavia - but we can nevertheless not talk about a common "Yugoslav historiography". ${ }^{14}$ Extensive joint projects, where their contributors "nearly perished due to excessive workload" (I am quoting Zdenko Čepič, who would often tell an anecdote about a leader of one of the projects, Dušan Bilandžić), remained unrealised, "while the exploration of the Yugoslav nations" past started moving more and more often into the realm of journalism, artistic works and especially 'pure politics", 15 as Božo Repe wrote. Sadly, most often that was where it remained. For the purposes of this contribution I have reviewed quite a collection of scientific publications, and under keyword "Yugoslavia" I have found quite a few peculiar ways in which this concept was used (sort of in the style of the permanent exhibition of the military museum at Kalamegdan, where the presentation of the Yugoslav military history started somewhere in the Iron Age). I have nevertheless found that in the middle of the 1980s a few reviews were written that may have partly opposed each other in their interpretations, but they still represent the basis for serious studies of the Yugoslav history (History of SFRY by

12 Stane Granda, "Zaklinjanje Titu je znak razpadanja uma in demence," [Swearing by Tito is a Sign of Disintegrating Minds and Dementia] Nova24tv, accesed 20 June 2016, http://nova24tv.si/ slovenija/ljudje/stane-granda-zaklinjanje-titu-je-znak-razpadanja-uma-in-demence/.

13 E.g. Zdenko Čepič, "Misli in dejstva: izhodišča," [Thoughts and Facts: Starting Points] in: Slovenija v Jugoslaviji, ed. Zdenko Čepič (Ljubljana: Inštitut za novejšo zgodovino, 2015), 5-19.

14 Mateja Režek, "Usmerjena preteklost. Mehanizmi ideološke in politične 'kontaminacije' zgodovinopisja v socialistični Sloveniji in Jugoslaviji," [Directed Past: Mechanisms of Ideological and Political 'Contamination' of Historiography in the Socialist Slovenia and Yugoslavia] Acta Histriae 22, No. 4 (2014): 971-92 and 977.

15 Božo Repe, "Zgodovina, zgodovinopisje in etika," [History, Historiography and Ethics] in: Etika v slovenskem jeziku, literaturi in kulturi. Zbornik predavanj / 49. seminar slovenskega jezika, literature in kulture, [Ljubljana], 1 - 12 July 2013, ed. Aleksander Bjelčević (Ljubljana: Znanstvena založba Filozofske fakultete, Ljubljana: 2013), 82, 83. 
Bilandžić, ${ }^{16}$ Yugoslavia $1918-1984$ by Petranović-Zečević, ${ }^{17}$ and Nations, Yugoslavia, Revolution by Janko Pleterski ${ }^{18}$ ). Despite the differences, the common historiographic space did exist. In the Contributions to Contemporary History (Prispevki za novejšo zgodovino) scientific journal we can thus follow reviews of works from the territory of the former state until around the end of 1992 (due to the relatively long delay in publication). In the same year three works focusing on the Slovenian history also in the Yugoslav context were published (Assumption of Power by Jera Vodušek Starič, ${ }^{19}$ Slovenian Industry in the Clutches of Yugoslavia by Jože Prinčič, ${ }^{20}$ and Liberalism by Božo Repe ${ }^{21}$ ). These were followed by quite a lengthy silence and we could say that the "republican historiography" with the purpose of strengthening the new state reality once again came to the forefront. However, the study programmes at the Department of History at the Faculty of Arts in Ljubljana managed to avoid this focus somehow. There we, the students, were still able to listen to lectures on the former common space, albeit under somewhat altered titles: for example, in 1991 the term "History of Yugoslav nations" was replaced by the collocation "History of South-East Europe". ${ }^{22}$

In the time of its dissolution and throughout of the 1990s Yugoslavia was at the centre of the international attention, especially due to the Yugoslav Wars. At this moment a turning point took place in Slovenia, and after the significant growth in the 1980s the Slovenian-centric historiography was in full swing. After all, the flood of exclusively foreign works about Yugoslavia and its neuralgic former component parts led to the fact that my colleague and I, when we researched this issue years ago, would refer to the works of foreign (English-speaking) and Serbian authors much more often than the few Slovenian and Croatian authors. The publication of Pirjevec's Yugoslavia in 1995, more than half of which is dedicated to the Second Yugoslavia, was an important reference point. ${ }^{23}$ However, even this book was ini-

16 The book was first published in 1979, in the Slovenian language in 1980, but here I am referring to the third, extended edition from the middle of the 1980s. - Dušan Bilandžić, Historija Socijalističke Federativne Republike Jugoslavije. Glavni procesi [History of the Socialist Federal Republic of Yugoslavia. The Main Processes: 1918-1985] (Zagreb: Školska knjiga, 1985).

17 The publication was then re-published and extended to include the period until 1988, and the authors continued writing about this topic in the 1990s. - Branko Petranović and Momčilo Zečević, Jugoslavija 1918-1984 [Yugoslavia 1918-1984] (Beograd: Rad, 1985).

18 Janko Pleterski, Nacije, Jugoslavija, revolucija [Nations, Yugoslavia, Revolution] (Beograd: Komunist, 1985). Slovenian edition Janko Pleterski, Narodi, Jugoslavija, revolucija (Ljubljana: Komunist and Državna založba, 1986).

19 Jerca Vodušek Starič, Prevzem oblasti 1944-1946 [Assumption of Power 1944-1946] (Ljubljana: Cankarjeva založba, 1992).

20 Jože Prinčič, Slovenska industrija v jugoslovanskem primežu [Slovenian Industry in the Clutches of Yugoslavia] (Novo mesto: Dolenjska založba, 1992).

21 Božo Repe, 'Liberalizem'v Sloveniji ['Liberalism' in Slovenia] (Ljubljana: RO ZZB NOV Slovenije, 1992).

22 Janez Mlinar, Oddelek za zgodovino. Zgodovina oddelka [Departmen of History. History of the Department], accesed 1 September 2016, http://www.zgodovina-ff-uni-lj.net/index.php?option=com_ content\&task=view\&id=20\&Itemid=42.

23 Jože Prijevec, Jugoslavija 1918-1992. Nastanek, razvoj ter razpad Karadjordjevićeve in Titove Ju- 
tially written for the Italian market, and only afterwards it was successfully published and well-received in Slovenia as well. Afterwards Jože Pirjevec wrote further works about the Yugoslav Wars and later also Tito. These were released in ideal publishing circumstances, but they did not transcend the importance of his book Yugoslavia, which therefore remains unsurpassed as the only synthetic work of this kind by a Slovenian author. In the words of Branko Goropevšek, "It is currently one of the few works written in the language of a small nation living under the Alps, whose contents do not stir up emotions in its readers and it is also not subject to sensationalism, which can often be claimed of similar political thrillers of this sort." ${ }^{\text {"24 }}$ Such thrillers are still in ample supply today. However, as I browse through the works of Slovenian historians I can establish that in Slovenia the new era of interest in the Yugoslav history in its broader context started after 2000 and after the change of the regime in the contemporaneous Federal Republic of Yugoslavia or Serbia. Slovenian historians finally regained access to archive sources, and in the interim a sort of a competitive spirit was formed, as in Serbia the Yugoslav history had been intensively dealt with, focused on in temporal and substantive stages, and often interpreted in a way which did not necessarily correspond to the Slovenian outlook on this period. ${ }^{25}$ Since my active engagement in research, the Second Yugoslavia has become increasingly important. Symposiums were organised on occasions of major anniversaries of the Yugoslav state; a research project dedicated to this very issue took place at the Institute of Contemporary History (Položaj in vloga Slovenije v jugoslovanski državi po drugi svetovni vojni 1945-1991 - Position and Role of Slovenia in the Yugoslav State after World War II 1945-1991); several collections of scientific texts have been published; individual researchers have placed their works into a broader context; and the exchange of visits and confrontation of opinions with the researchers from other former Yugoslav territories has gradually become a constant.

The second issue involves the evaluation of the Yugoslav experience and is discussed in the third part of this contribution. Many people have focused on Yugoslavia in various contexts and times. Their evaluations differed and were sometimes even conflicting, so that the readers sometimes even felt that these assessments were made under the influence of the constant requirements of daily politics, as the events from the times of Yugoslavia and its disintegration are still present not only in the parliamentary discussions, but also in the main TV news programmes and lately even in the crime sections in the press. Perhaps this indicates that we, as a society,

goslavije [Yugoslavia 1918-1992. Origin, Development and Disintegration of Karađorđevićs and Tito's Yugoslavia] (Koper: Lipa, 1995).

24 Branko Goropevšek, "Kot steklenica piva na smetišču," [Like a Beer Bottle in the Dump] Zgodovina za vse 3, No. 1 (1996): 87, 88.

25 Here we should mention an interesting fact that in the last 25 years the First Yugoslavia has acquired a markedly better reputation in the Slovenian historiography. This does not only mean a more lenient view of its political regime, which simply was not seen positively in the second Yugoslav state, but also the outlook on the position of Slovenians in this state. This, for example, is not comparable with the other former Yugoslav historiographies, where the image of the First Yugoslavia has remained more similar to the former views. This is especially true of Serbia. I would like to thank Peter Vodopivec for this note. 
have still not got over the dissolution of the "marriage". Many authors were also quite unoriginal. For example, if we look at one of the formulations from the conclusion in Silvo Kranjec's book Kako smo se zedinili (How We Have United) of 1928, we can soon establish that a formula exists for a successful ending of every text about the Slovenian national decisions:

"Thus our unification was acknowledged and confirmed in the international agreements, where we Slovenians were mentioned for the first time. After long centuries of foreign yoke we have joined the family of free nations as an equal member... /.../ This very formation of our current state teaches us that it is impossible to vanquish an educated and honest nation and that no man can permanently separate what God has joined together." 26 (underlined by J. H.)

From a myriad of opinions I have extracted the records of three Slovenian historians who wrote about this topic constantly and through a lengthy time period: Janko Pleterski, Božo Repe and Dušan Nećak.

The following quote from Dušan Nećak’s article 70 let Jugoslavije - obletnice in prelomnice (70 Years of Yugoslavia - Anniversaries and Turning Points) of 1989, written on a similar occasion as we are celebrating today, shows how thoughts depend on the circumstances and how much easier it is to observe the historical circumstances from an all-knowing position thirty years later. ${ }^{27}$

"In 1988 the 'point zero!' of the general Yugoslav development was reached. Only through domination of rationality over emotions and, I hope, because of the realisations stemming from historical experience - that only a democratic Yugoslavia is a homeland of all nations and nationalities under the condition that everyone in it feels nationally and socially safe and equal and that it is strong only in so far as its constituent parts are strong - an explosion has, for now, not taken place. If we can keep learning from historical experience, it shall also never happen". 28

The same author appeared at a very interesting colloquium entitled Jugoslavija zgodovinska nuja ali zmota (Yugoslavia - a Historical Necessity or Mistake), which indicates that the question of evaluating the Slovenian experience in the former state despite the professed historiographical love or the need for temporal distance was an important social issue. Here, well over five years later, Nećak said:

"From all of the above it is nevertheless clear that Yugoslavia was a historical necessity also for the Slovenian nation. It was an unavoidable historical transference in which the Slo-

26 Silvo Kranjec, Kako smo se zedinili [How We Have United] (Celje: Družba sv. Mohorja, 1928), 142.

27 The seventy-year anniversary of the establishment of the first Yugoslav state.

28 Dušan Nećak, "70 let Jugoslavije - obletnice in prelomnice," [70 Years of Yugoslavia - Anniversaries and Turning Points] Časopis za zgodovino in narodopisje 60, No. 1 (1989): 31, 32. 
venian nation had matured to the degree where it was able to undertake the formation of its own sovereign state. With its own nation Slovenians received an opportunity to decide independently about its own destiny and future. We must also assume the responsibility for every decision about the potential new, old, or ancient integrations." 29

The very title of the symposium attests to the spirit of the times. Božo Repe stated: "We historians focused on Yugoslavia from the viewpoint of a done fact. It is simply our job. We were looking for traces of logical developments from the Yugoslav idea until the creation and functioning of the state." 30 Quite a few years later he went on to add:

“The today's Slovenian outlook on Yugoslavia, especially the political outlook - and this is partly true also of historians - stems from the theory that Yugoslavism was a kind of a provisional solution, something that helped Slovenians overcome the difficult times until they were able to return where they belonged: to the so-called 'Europe.."31

From the today's distance, when we have been dwelling in the so-called Europe for quite a while and when this historical goal has been achieved, this issue is not at the forefront anymore. Especially if we think of what is today a very popular (and populist) comparison between the mastodonically bureaucratic but politically weak European Union, whose members include states on very different levels of development, and Yugoslavia. At this point we can refer to the well-known thought of the last Yugoslav President of the Government (or President of the Federal Executive Council) Ante Marković, who saw Yugoslavia as a convoy of ships in which the last ship, i.e. Kosovo, was seven times slower than the rest. Thus Božo Repe removes Europe from the forefront in a university textbook:

"Circumstances have forced Slovenia to leave Yugoslavia: the increasing gap between Yugoslavia and the developed countries, but primarily the inability of Yugoslavia to democratise and modernise itself as well as ensure the national rights to its nations. It was this combination of liberal ideas and national feelings that created enough mass energy in Slovenia to allow for the envisioned goals to be carried out." 32

29 Dušan Nećak, "Jugoslavija, historična nujnost ali napaka?," [Yugoslavia, a Historical Exigency or a Mistake?] Časopis za zgodovino in narodopisje 65, No. 1 (1994): 70, 71.

30 Božo Repe, "Jugoslavija - zgodovinska nuja ali zgodovinska zmota," [Yugoslavia: A Historical Necessity or a Historical Mistake?] Casopis za zgodovino in narodopisje 65, No. 1 (1994): 73.

31 Božo Repe, "Zakaj so Slovenci vstopili v Jugoslavijo in zakaj so iz nje odšli??” [Why Slovenians Entered Yugoslavia and Why They Left It], in: Jugoslavija v času. Devetdeset let od nastanka prve jugoslovanske države, [Yugoslavia in Time. Ninety Years from the Formation of First Yugoslav State] ed. Bojan Balkovec (Ljubljana: Oddelek za zgodovino Filozofske fakultete, 2009), 23.

32 Božo Repe, Jugoslovanstvo kot ideja in kot praksa [Yugoslavism as Idea and Practice] (Ljubljana: Filozofska Fakulteta-Oddelek za zgodovino, 2016), 148, accesed 1 September 2016, http://www.zgodovina-ff-uni-lj.net/index.php?option=com_remository\&Itemid=26\&func=startdown\&id=67 . 
Naturally, he also adds the international context that made this possible. To the following empty phrase - the so-called thousand-year dream - we should also add the following finding from the aforementioned textbook:

"Despite its constant dissatisfaction Slovenia believed in the Yugoslav state. It invested extraordinary amounts of energy in its existence and its system, and the Slovenian political and economic elites had significant influence in the state leadership already in the First, but even more so in the Second Yugoslavia. Therefore nobody thought of seeking any solutions outside of Yugoslavia until the very end of the 1980s."

When I said something similar in a radio broadcast on the occasion of the referendum about the independence of Slovenia, the journalist just gaped at me in wonder. ${ }^{33}$

However, the point of this contribution lies elsewhere: not so much in the interpretations, but rather in the context in which this chapter of the Slovenian history should be explored. Already Janko Pleterski discussed this at the Maribor symposium, where he talked about the plundering of history ${ }^{34}$ : "Only a comprehensive, unplundered history can be the proverbial bough on which one can sit. No matter whether the tree from which this bough grows was once called the Habsburg Empire, yesterday Yugoslavia, or today simply Europe."35

\section{Sources and Literature}

Literature:

- "Hiti počasi.” Hiti počasi - Wikipedija, prosta enciklopedija. Accesed 20 June 2016. https:// sl.wikipedia.org/wiki/Hiti_po\%C4\%8Dasi.

- Avanzo, Miha. "Kje končajo mrtve države?." [Where Do Dead Countries End Up] In: Dejan Novačić, SFRJ - moja dežela: turistični vodnik, 4. Ljubljana: Orbis, 2003.

- Bilandžić, Dušan. Historija Socijalističke Federativne Republike Jugoslavije. Glavni procesi: 1918-1985 [History of the Socialist Federal Republic of Yugoslavia: the Main Processes: 1918-1985]. Zagreb: Školska knjiga, 1985.

- Čepič, Zdenko. "Misli in dejstva. Izhodišča." [Thoughts and Facts: Starting Points] In: Slovenija v Jugoslaviji, ed. Zdenko Čepič, 5-19. Ljubljana: Inštitut za novejšo zgodovino, 2015.

- Čuček, Filip, Jurij Hadalin, Jure Gašparič and Ivan Merljak. "Strta pričakovanja (Sledi časa)." [Broken Expectations (Traces of Time)] Radio Slovenija, programme I (23 December 2012). Accesed 1 September 2016. http://tvslo.si/predvajaj/strta-pricakovanja/ava2.153826307/.

- Goropevšek, Branko. "Kot steklenica piva na smetišču." [Like a Beer Bottle in the Dump] Zgodovina za vse 3, No. 1 (1996): 85-88.

- Granda, Stane. "Zaklinjanje Titu je znak razpadanja uma in demence." [Swearing by Tito is a Sign of Disintegrating Minds and Dementia] Nova24tv. Accesed 20 June 2016. http://nova24tv.si/slovenija/ljudje/stane-granda-zaklinjanje-titu-je-znak-razpadanja-uma-in-demence/.

33 Filip Čuček, Jurij Hadalin, Jure Gašparič and Ivan Merljak, "Strta pričakovanja (Sledi časa)," [Broken Expectations (Traces of Time)] Radio Slovenija, programme I (23 December 2012), accesed 1 September 2016, http://tvslo.si/predvajaj/strta-pricakovanja/ava2.153826307/.

34 The plundering of history has been characteristic of the former Eastern Bloc countries. I see it as reaching into a cookie jar and taking only what you find useful, while leaving and discarding the rest.

35 Janko Pleterski, "Jugoslavija v slovenski zgodovini," [Yugoslavia in the Slovenian History] Časopis za zgodovino in narodopisje 65, No. 1 (1994): 45. 
- Kamusella, Tomasz. The Forgotten 1989 Ethnic Cleansing of Bulgaria's Turks. A Yugoslav Connection? (lecture). Ljubljana: Faculty of Arts and Institute of Contemporary History, 7 June 2016.

- Kranjec, Silvo. Kako smo se zedinili. [How We Have United] Celje: Družba sv. Mohorja, 1928.

- Krečič, Jela. Miglena Nikolčina: Treba je tvegati in si zamisliti utopijo [We Have to Take a Risk and Imagine an Utopia]. Accesed 1 September 2016. http://m.delo.si/sobotna/miglena-nikolcina-treba-je-tvegati-in-si-zamisliti-utopijo.html.

- List of Wikipedias-Meta. Accesed 20 June 2016. https://meta.wikimedia.org/wiki/List_of_ Wikipedias\#All_Wikipedias_ordered_by_number_of_articles.

- Mlinar, Janez. Oddelek za zgodovino. Zgodovina oddelka. [Department of History. History of the Department] Accesed 1 September 2016. http://www.zgodovina-ff-uni-lj.net/index. php?option=com_content\&task=view\&id=20\&Itemid $=42$.

- Nećak, Dušan. "70 let Jugoslavije - obletnice in prelomnice." [70 Years of Yugoslavia - Anniversaries and Turning Points] Časopis za zgodovino in narodopisje 60, No. 1 (1989): 15-32.

- Nećak, Dušan. "Jugoslavija, historična nujnost ali napaka?." [Yugoslavia, a Historical Exigency or a Mistake?] Časopis za zgodovino in narodopisje 65, No. 1 (1994): 67-71.

- Novačić, Dejan. Emigrantski kuvar. Sve što ste oduvek hteli da znate o jugoslovenskoj kuhinji, ali nemate više koga da pitate. [Emigrant Cookbook. What You've Always Wanted to Know about the Yugoslav Kitchen, but There's No One Left to Ask] Novi Sad: Stylos Art, 2009.

- Novačić, Dejan. SFRJ - moja dežela. Turistični vodič. [SFRY - My Country. A Tourist Guide] Ljubljana: Orbis, 2003.

- Novačić, Dejan. SFRJ za ponavljače. Turistički vodič. [SFRY for Repeaters. A Tourist Guide] Beograd: Moć knjige, 2003.

- Petranović, Branko and Momčilo Zečević. Jugoslavija 1918-1984. Zbirka dokumenata. [Yugoslavia 1918-1984. Collection of Documents] Beograd: Rad, 1985.

- Pirjevec, Jože. Jugoslavija 1918-1992. Nastanek, razvoj ter razpad Karadjordjevićeve in Titove Jugoslavije. [Yugoslavia 1918-1992. Origin, Development and Disintegration of Karađorđevićs and Tito's Yugoslavia] Koper: Lipa, 1995.

- Pleterski, Janko. "Jugoslavija v slovenski zgodovini." [Yugoslavia in the Slovenian History] Casopis za zgodovino in narodopisje 65, No. 1 (1994): 40-46.

- Pleterski, Janko. Nacije, Jugoslavija, revolucija. [Nations, Yugoslavia, Revolution] Beograd: Komunist, 1985.

- Pleterski, Janko. Narodi, Jugoslavija, revolucija. [Nations, Yugoslavia, Revolution] Ljubljana: Komunist and Državna založba Slovenije, 1986.

- Prinčič, Jože. Slovenska industrija v jugoslovanskem primežu. Kapitalna, ključna kapitalna in temeljna investicijska izgradnja v Sloveniji: 1945-1956. [Slovenian Industry in the Clutches of Yugoslavia. Capital, Key Capital and Basic Investment Development in Slovenia: 1945-1956] Novo mesto: Dolenjska založba, 1992.

- Repe, Božo. 'Liberalizem'v Sloveniji. ['Liberalism' in Slovenia] Ljubljana: RO ZZB NOV Slovenije, 1992.

- Repe, Božo. "Jugoslavija — zgodovinska nuja ali zgodovinska zmota." [Yugoslavia: A Historical Necessity or a Historical Mistake?] Časopis za zgodovino in narodopisje 65, No. 1, (1994): 72-76.

- Repe, Božo. Jugoslovanstvo kot ideja in kot praksa. [Yugoslavism as Idea and Practice] Ljubljana: Filozofska Fakulteta-Oddelek za zgodovino, 2016. Accesed 1 September 2016. http://www.zgodovina-ff-uni-lj.net/index.php?option=com_remository\&Itemid=26\&func=startdown\&id=67.

- Repe, Božo. "Zakaj so Slovenci vstopili v Jugoslavijo in zakaj so iz nje odšli?." [Why Slovenians Entered Yugoslavia and Why They Left It] In: Jugoslavija v času. Devetdeset let od nastanka prve jugoslovanske države, [Yugoslavia in Time. Ninety Years from the Formation of First Yugoslav State] ed. Bojan Balkovec, 21-46. Ljubljana: Oddelek za zgodovino Filozofske fakultete, 2009.

- Repe, Božo. "Zgodovina, zgodovinopisje in etika." [History, Historiography and Ethics] In: Etika $v$ slovenskem jeziku, literaturi in kulturi. Zbornik predavanj / 49. seminar slovenskega jezika, literature in kulture, [Ljubljana], 1 - 12 July 2013, ed. Aleksander Bjelčević, 81-88. Ljubljana: Znanstvena založba Filozofske fakultete, Ljubljana, 2013. 
- Retrostalgija [Retronostalgia] | Radio Študent. Accesed 1 September 2016. http://radiostudent.si/ $\mathrm{dru} \% \mathrm{C} 5 \% \mathrm{BEb}$ a/retrostalgija.

- Režek, Mateja. "Usmerjena preteklost: Mehanizmi ideološke in politične 'kontaminacije' zgodovinopisja v socialistični Sloveniji in Jugoslaviji." [Directed Past: Mechanisms of Ideological and Political "Contamination" of Historiography in the Socialist Slovenia and Yugoslavia] Acta Histriae 22, No. 4 (2014): 971-92.

- Šifrer, Andrej. “Država”. Hiti počasi. Ljubljana: ZKP RTVLJ, 1990.

- Tito's Home Page. At: www.titoville.com. Website currently unavailable.

- Ugrešić, Dubravka. "Leksikon izmišljene dežele." [Lexicon of an Imaginary Country]. In: Dejan Novaćić, SFRJ - moja dežela. Turistični vodič, 5-6. Ljubljana: Orbis, 2003.

- "United States Census Bureau, American Fact Finder, Ancestry (Total Categories Tallied) for People with One or More Ancestry Categories Reported." American FactFinder - Results. Accesed 20 June 2016. http://factfinder.census.gov/faces/tableservices/jsf/pages/productview.xhtml?pid=DEC_00_ SF3_PCT018\&prodType=table.

- Vodušek Starič, Jera. Prevzem oblasti 1944-1946. [Assumption of Power 1944-1946] Ljubljana: Cankarjeva založba, 1992.

\begin{tabular}{c}
$\frac{\text { Jurij Hadalin }}{\text { NEZAŽELENA DEDIŠČINA? HISTORIOGRAFSKI DISKURZ O (DRUGI) JUGOSLAVIJI }}$ \\
\hline P O V ZE T E K
\end{tabular}

O drugi jugoslovanski državi so $\mathrm{v}$ različnih kontekstih in časovnih razmakih razmišljali mnogi. Postavili so različne ocene, ki se med seboj včasih tudi bijejo, tako da ima bralec včasih občutek, da so nastale predvsem pod vplivom nenehnih potreb dnevne politike, saj je dogajanje iz časov Jugoslavije in njenega konca še vedno prisotno ne le v parlamentarni razpravi, ampak je izpostavljeno v osrednjih informativnih oddajah in zadnje čase celo črnih kronikah. Kar morda kaže, da konca "zakonskega razmerja" kot družba še vedno nismo preboleli. Bolečih oz. perečih tem se navadno ob praznovanjih ogibamo, a politično, zemljepisno in tudi kulturno nas je Jugoslavija determinirala do te mere, da ob 25. obletnici samostojne slovenske države preprosto ne moremo mimo nje.

Avtor je pod drobnogled vzel tri povezane tematike. V prvem delu razprave najprej opravi s fenomenom t. i. "jugonostalgije", ki je danes v družbi precejšen kamen spotike, pomembno pa prispeva tudi $\mathrm{k}$ ugledu in pomenu druge jugoslovanske države $v$ širši javnosti. $V$ drugem delu sestavka se posveti vprašanju obstoja jugoslovanske historiografije in odnosu slovenskega zgodovinopisja do druge Jugoslavije. $\mathrm{V}$ tretjem delu članka nato na podlagi zapisov treh uveljavljenih slovenskih zgodovinarjev iz različnih obdobij zadnjega tridesetletja poskuša predstaviti še spremembe v vrednotenju jugoslovanske izkušnje.

Razprava ni namenjena temu, da bi na enem mestu in z obširno analizo poskušali rešiti zgoraj navedena vprašanja, predstavlja zgolj kritični preblisk in želi doseči nekoliko širšo obravnavo problema, upoštevajoč širše kontekste, ki v današnjem zgodovinopisju še vedno občasno umanjkajo. 